\title{
Correction to: Can Fluid Interaction Influence the Critical Mass for Taxis-Driven Blow-up in Bounded Planar Domains?
}

\author{
Michael Winkler ${ }^{1}$
}

Published online: 24 September 2021

(c) The Author(s) 2021

\author{
Correction to: Acta Appl. Math. (2020) 169: 577-591 \\ https://doi.org/10.1007/s10440-020-00312-2
}

The article "Can Fluid Interaction Influence the Critical Mass for Taxis-Driven Blow-up in Bounded Planar Domains?", written by Michael Winkler, was originally published Online First without Open Access. After publication in volume 169, issue 1, page 577-591 the author decided to opt for Open Choice and to make the article an Open Access publication. Therefore, the copyright of the article has been changed to (C) The Author(s) 2020 and the article is forthwith distributed under the terms of the Creative Commons Attribution 4.0 International License, which permits use, sharing, adaptation, distribution and reproduction in any medium or format, as long as you give appropriate credit to the original author(s) and the source, provide a link to the Creative Commons licence, and indicate if changes were made. The images or other third party material in this article are included in the article's Creative Commons licence, unless indicated otherwise in a credit line to the material. If material is not included in the article's Creative Commons licence and your intended use is not permitted by statutory regulation or exceeds the permitted use, you will need to obtain permission directly from the copyright holder. To view a copy of this licence, visit http:// creativecommons.org/licenses/by/4.0.

Funding Note Open Access funding enabled and organized by Projekt DEAL.

Publisher's Note Springer Nature remains neutral with regard to jurisdictional claims in published maps and institutional affiliations.

Open Access This article is licensed under a Creative Commons Attribution 4.0 International License, which permits use, sharing, adaptation, distribution and reproduction in any medium or format, as long as you give appropriate credit to the original author(s) and the source, provide a link to the Creative Commons licence, and indicate if changes were made. The images or other third party material in this article are included in the article's Creative Commons licence, unless indicated otherwise in a credit line to the material. If material is not included in the article's Creative Commons licence and your intended use is not permitted by statutory regulation or exceeds the permitted use, you will need to obtain permission directly from the copyright holder. To view a copy of this licence, visit http://creativecommons.org/licenses/by/4.0/.

The original article can be found online at https://doi.org/10.1007/s10440-020-00312-2

M. Winkler

michael.winkler@math.uni-paderborn.de

1 Institut für Mathematik, Universität Paderborn, 33098 Paderborn, Germany 